This item was submitted to Loughborough's Research Repository by the author.

Items in Figshare are protected by copyright, with all rights reserved, unless otherwise indicated.

\title{
Nicholas Rengger and two wars
}

PLEASE CITE THE PUBLISHED VERSION

https://doi.org/10.1177/0047117820968620

PUBLISHER

SAGE

VERSION

AM (Accepted Manuscript)

\section{PUBLISHER STATEMENT}

This paper was accepted for publication in the journal International Relations and the definitive published version is available at https://doi.org/10.1177/0047117820968620. Users who receive access to an article through a repository are reminded that the article is protected by copyright and reuse is restricted to noncommercial and no derivative uses. Users may also download and save a local copy of an article accessed in an institutional repository for the user's personal reference.

\section{LICENCE}

CC BY-NC-ND 4.0

\section{REPOSITORY RECORD}

Kennedy-Pipe, Caroline. 2020. "Nicholas Rengger and Two Wars". Loughborough University. https://hdl.handle.net/2134/13687942. 


\begin{abstract}
Nicholas Rengger spent much of his career thinking and writing on the phenomenon of war. Eschewing any optimistic view that war could be abolished he also challenged the application of Just War theory to explain and justify the use of military force after the events of 9/11. His intellectual interactions with Jean Bethke Elshtain highlighted his growing unease with those in International Relations who sought to render palatable the use of torture, extraordinary rendition and technological 'fixes' in the pursuit of Western interests.
\end{abstract}

Keywords: War, Just War, Cold War, War on Terror, Elshtain, Moralism.

\title{
Nicholas Rengger and Two Wars
}

\section{Caroline Kennedy-Pipe}

Writing on the state of war in 2008 Nicholas Rengger challenged the notion that there was much to be optimistic about in contemporary global politics. ${ }^{\mathrm{i}}$ He took particular issue with those such as John Mueller who claimed that war had gone out of fashion along with arcane rituals such as duelling or inhumane practices such as slavery. War could in his view 'shrivel up and disappear' ii War had not, in Rengger's opinion, though been 'unlearnt'. For much of the first decade of the twenty-first century, he spent his time unleashing academic shots across the bows of colleagues such as Robert Keohane and Joseph Nye who had pretty much since the 1990s stressed (somewhat naively in Rengger' s view) the primacy of soft as opposed to hard power. ${ }^{\text {iii }}$ Rengger also intellectually jousted with those scholars who believed that the 'thickness' of international law, a certain type of humanitarianism and liberalism could mitigate the essential darkness of international politics. ${ }^{\text {iv }}$ The utilisation of Just War theory in support of the 9/11 wars became a particular 'bete noire' and the subject of many of his articles and a book. 
Overall, then, his career within the academy of International Relations was one of a combative if always courteous intellectual stance. His shards of opposition to much of the goings on in IR were rooted in what had over many years become essentially a very specific view of war: a belief that war is always with us, unlikely to be abolished and certainly not tamed by technology. This stance was apparent long before the events of $9 / 11$ but became ever more evident in the years following that tragedy. So, in this essay I want to reflect on Rengger's engagement with IR through two wars: the 'Cold War' and the 'War on Terror' but also assess his overall contribution through his critique of a figure he greatly admired but then became somewhat puzzled by, the American theologian and philosopher, Jean Bethke Elshtain.

In a glittering essay on Bethke Elshtain and her 'take' on $9 / 11,{ }^{\mathrm{v}}$ Rengger picked up and articulated the views of those who believed that the 'War on Terror' had taken many pernicious turns in respect of human rights and international law. An even sharper concern was that the Elshtain response to 9/11 was based on a wilful misunderstanding of the shape of global politics. a general misappropriation and misapplication of Just War Theory and a distortion of the role of the scholar in public life.

For Rengger, any credible version of IR had to understand the continuities and trajectories of global politics and not rest on a single event. It was imperative therefore not to catastrophise certain incidents such as 9/11 (to which we will return) but understand events through the lens of a landscape in which historical, cultural and religious sentiment had to be interrogated. (On this he certainly agreed with Elshtain about the need to incorporate theological readings into the curriculum). Logically, therefore any analysis of the events of the Cold War or its many different parts could not be seen or studied as a discrete or standalone event. This viewpoint challenged much, if not all, traditional Cold War studies and most IR theory which tended to use instances such as the Cuban Missile Crisis to extrapolate 
general lessons without really explaining historical context. In this respect, any idea that the four decades after 1945 had formed a Long Peace or a European fairy tale ${ }^{\mathrm{vi}}$ which had ended the unhealthy militarism of the European system was simply wrong headed. The Cold War was no holiday from history, rather that period was a continuation of a longer-term trend in European history in which a certain type of moralism underpinned Western politics. The Cold War had become the supreme manifestation in which war was not a terrible necessity fought when something critical was at stake, such as national survival, but a deadly mechanism for pursuing liberal values abroad. Here Rengger was especially vexed with Elshtain's view that there was and should be no cleavage between domestic and foreign policy profoundly disagreeing that American values however constituted at home could act as a universal panacea abroad.

He accepted that in the US case, moralism trumped politics: hence any justification for war (whether it be nuclear, limited or proxy war) was linked to fighting regimes of a certain stripe. In the Cold War this took the form of opposition to Communism which had after the defeat of Nazi Germany replaced the foe of fascism. Later, deadly enemies would be found in the 'axis of evil' and in al-Qaeda plus its associated groups. For Rengger following in the footsteps of Noel O'Sullivan ${ }^{\mathrm{vii}}$ - the problem was that in both the Cold War and then in the 'War on Terror' opponents could not be permitted to exist nor simply contained. The international arena had become rather a world in which the 'real meat' of international politics - that of careful state to state engagement, a balancing and recognition of competing national interests and traditional diplomacy - was eschewed. Most importantly, the Cold War system was built on will, artifice and crucially for Rengger a form of righteousness.

This righteousness, (apparent in Elshtain's work) had roots in revolutionary France and its attempts to eradication monarchy, in the First World War and the demand to 'hang 
the Kaiser' as well as in the Russian Revolution when again ideology demanded the execution of the Tsar, his family and the ruling classes. ${ }^{\text {vii }}$ The Cold War continued this tradition of moral as well as material absolutism.

The logic (or illogic) of the Cold War and the advent of the nuclear age meant that wars became bloodier - at least for those on the other side. Narratives of this period after World War II commonly start with the enunciation of 'Unconditional Surrender' by FDR meaning that enemies could not be negotiated with those opposed to democracy must be eliminated not chastised through another failed settlement as at Versailles or at Munich. Hence, once the Soviet Union/Communism had been deemed 'abnormal' (indeed a malignant parasite) by George Kennan, ${ }^{\text {ix }}$ and later an evil empire by Reagan that thesis underpinned successive US administrations and allies, Containment, not diplomacy, dominated the Cold War, thus obviating any need for meaningful engagement between the so-called first and second worlds. A bifurcation of the world (which was of course perceived as a predominantly European world) symbolised by the division of Germany meant that brinksmanship, nuclear and conventional as in 1948 and 1961, maintained an unsteady peace. When military force was deployed as in Vietnam, realists such as Hans Morgenthau (a figure Rengger greatly admired) lamented a war not just badly fought but undertaken for ideological, not national purpose. ${ }^{\mathrm{x}}$ Kennan himself, of course, came to deplore how his original and somewhat narrow conception of Containment had morphed into a geopolitical competition that had by the early 1980 s become all encompassing. ${ }^{\text {xi }}$ Like both Morgenthau and Kennan, Rengger disapproved of the tendency of the United States to engage in moral crusading. Indeed, Elshtain's robust endorsement of the moral component of the Bush 'War on Terror' in particular perplexed Rengger even though he had noted on more than one occasion the celebration of American civic virtue, patriotism (in her words a chastened patriotism) and US moralism threaded throughout her scholarship both during the Cold War 
and after. In this respect Elshtain was remarkably consistent in her admission that she spoke and wrote as 'a citizen'. As we will go on to see, Rengger throughout his career rejected any such linkage between the duties of a citizen and those of a scholar.

The seemingly sudden demise of the Soviet Union caused shock within the IR scholarly community; while few had foreseen the collapse of the forever system of bi-polarity many took the opportunity to celebrate not just the triumph of Western ideology but the opportunity to reshape IR theory, jettisoning traditional Strategic Studies and the study of war in favour of an emphasis on Critical approaches, human security and emancipatory politics. Quite a few scholars though were rather bewildered by the loss of the Soviet enemy and the rapid shift into new fields of endeavour.

Rengger, unlike many of our generation in IR, was not intellectually lost after the collapse of Soviet Communism. He did not flounder. His acute historical sensibility and his appreciation of the unending cycle of the rise and fall of the great powers meant he saw the Soviet collapse as, if not natural, then somehow inevitable in the face of the supposed boundlessness of US power ${ }^{x i i}$. Here he, rather unusually saw 9/11 as arising from Cold War politics and coming out of the Superpower struggle. Nested in the years of US interventions, both overt and covert across the Middle East, for Rengger (who recommended Lawrence Wright's Looming Tower to colleagues and students alike) the ambitions of Osama bin Laden had been forged not just in the CIA funded campaign against the Soviet Union in Afghanistan during the 1980s but in the events of the first Gulf War of 1990 and the expansion of US power and influence in the Middle East. Blow-back from years of involvement in Saudi Arabia in particular had led to the catastrophic attacks on the US homeland. Men with boxcutters attacked the greatest military power on earth and, in doing so, spawned not just 'The War on Terror' but a rapid proliferation of terrorism studies of both a critical and traditional hue. 
Interesting though the resurgence of academic studies in terrorism was to Rengger, especially in his role as Head of Department at St Andrews, he was more intrigued by the manner in which $9 / 11$ created the permissive environment in which the West could do things it had wanted to do for a long time. This included the reshaping of the politics of the Middle East through nation building, the securing of oil fields and the removal (finally) of entrenched foes such as Saddam Hussein. The wars in Afghanistan and then in Iraq, both proved to be military as well as political disasters. Despite overwhelming military power, Afghanistan turned in to America's longest war while the Iraq intervention spawned ISIS. Throughout these years Rengger did not transform himself into either an expert on COIN or venture into the punditry of commenting on regional politics, Rather he directed his pique towards the cooption of the Just War theory by those who supported military intervention and particularly those who utilised the theory to justify the use of armed drone strikes. His concern over the use of torture, extraordinary rendition were issues which profoundly dispelled his admiration for Elshtain, when she appeared to excuse some forms of ill treatment of detainees.

She seemed, at least to Rengger, to have abandoned many of the guiding principles of her scholarship undertaken in a long and distinguished career through her public endorsement of the Bush War on Terror and those associated infringements of human rights. Her meeting for example with the President startled Rengger He was not however discomforted by her justifiable anger at the assault on the US nor indeed by her criticism of some intellectuals such as Jean Baudrillard for the view that 9/11 represented in part a reaction that 'we' all wanted to attack the US since it had roused all the world's innate violence. Rather Rengger' $s$ disquiet arose from a profound disagreement over the role of the pubic intellectual, with her position on measures such as extraordinary rendition and torture and most profoundly with her use of the Just War theory in defence of America exceptionalism. 
Let us start with that last issue: Rengger was galvanised intellectually in the years after the 'end of history' with the revival of the Just War tradition as a framework for the liberal politics of the 1990s. He lamented the co-option of the tradition to justify and encourage war rather than as a discussion for pursuing the prudent path of constraining war. ${ }^{\text {xii }}$ The emphasis in the 1990 s on military intervention was therefore but one sorry example of Western meddling. War should be as in a Clausewitzian world - a world of the logic of war as politics - and essentially a realpolitik fusion of the maximisation of the state and it's the national interest. Wars should not be simple wars of choice or justified somewhat cynically through simplified check lists or tick boxes of a 'just war' criteria. The utilisation of the Christian tradition of Just War and its application against those with opposing beliefs was particularly prevalent during the decade after the supposed end of history. And this was increasingly problematic because as the Twentieth Century came to a close, war had changed its essential character. As Mary Kaldor argued in her influential thesis of New Wars ${ }^{\text {xiv }}$, war was a phenomenon that was now sub state, irrationally and primitively violent, premised on ethnic identity and fuelled by globalisation. The question was whether any Just War application could have any real purchase other than providing a rationale for Western interventions, which necessarily—whatever the arguments over proportionality and so onmeant the deaths and displacement of many thousands of peoples. Rengger can be, has been accused of confining his work on European and Christian scholars in too narrow a fashion but his retort was usually that for good or ill the world or his world was still essentially a Westphalian world. Perhaps had he lived longer he may have addressed the accusation that he never extended his analysis to the use of force by states against their own citizens or an examination of the conditions under which the domestic militarisation of the state occurred. Perhaps, but he was certainly aware of the state and the way in which civil institutions feed off the business of war 
In some of the just war literature to which Rengger contributed there is a profound and unusual sense of the essential ugliness of war, but also its capacity to surprise with acts of heroism, compassion and sacrifice on an individual level. The decline of the warrior's honour, as Michael Ignatieff would have it, was a notion to be respected but not accepted. ${ }^{\mathrm{xv}}$ War for theorists like Rengger had to be, and had to remain, a human activity even in an age of airpower, drones and robots. ${ }^{\mathrm{xi}}$ Virtual Wars and risk free wars, again, enabled conflict rending it more palatable for liberal states but not for those on the other side.

For Rengger therefore if there could be any sanity in war, any amelioration of its folly, it was through the agency of the human not the machine: to look the enemy in the eye, not from Creech Air Force base and a drone booth, but human to human.

This emphasis on the human led him to question and deplore the seeming endorsement by Elshtain of the mistreatment of detainees under the Bush Administration. Even more profoundly Rengger did not agree with Elshtain that it was a duty to comment as a scholar on public affairs but rather he agreed with Oakeshott that the aim of theorising was purely intellectual with no purchase outside of the Academy. In fact, on reflection Rengger' $s$ disquiet with Elshtain after $9 / 11$ arose really from a difference not just in ideology but in temperament. Seamus Heaney reflecting on his career once said that he had the inclination not to' weigh in' but to 'weigh matters up'. That too was Rengger' s position. 


\footnotetext{
ii Nicholas Rengger and Caroline Kennedy-Pipe, 'The State of War' International Affairs,84 95),2008, pp.891901.

ii John Mueller, Quiet Cataclysm Reflections on the Recent Transformation of World Politics (New York: HarperCollinsCollegePublishers,1995). See on the shrivelling of war his piece 'The Obsolescence of Major War' in Bulletin of Peace Proposals. Vol.21, (3) Sept, 1990.

iii Robert O. Keohane and Joseph S. Nye, Jr., 'Power and Interdependence in the Information Age' in Foreign Affairs, 77 (5), Sept/Oct 1998.

iv Nicholas Rengger, "The Judgment of War: On the Idea if Legitimate Force in World Politics" Review of International Studies, Vol. 31, Supplement S1 (Force and Legitimacy in World Politics) December 2005, pp,143161.

' Nicholas Rengger, 'Just a War against terror? Jean Bethke Elshtain's burden and American power' International Affairs, January 3004, 80 (!), p.107-116.

vi John Lewis Gaddis, 'The Long Peace Elements of Stability in the Post war International System' International Security, 10 (4), Spring 1986, pp 99-142.

vii Noel O'Sullivan, Terrorism, Ideology \& Revolution The Origins of Modern Political Violence (Brighton: Harvester, 1986)

viii O'Sullivan, Terrorism, Ideology and Revolution, pp.7-10.

${ }^{i x}(X)$ George.F. Kennan, 'The Sources of Soviet Conduct' Foreign Affairs, July1947.

${ }^{x}$ Nicholas Rengger, 'Realism, Tragedy and the Anti-Pelagian Imagination in International Relations' in Michael C, Williams (ed) Realism Reconsidered The Legacy of Hans Morgenthau in International Relations' (Oxford: Oxford University Press, 2017) pp.118-136.

xi George F. Kennan, Around the Cragged Hill: A Personal and Political Philosophy (New York: W.W.Norton, 1993)

xii I am grateful to Dr Vassilios Paipais for this insight and phrasing re Nick's view of the end of the Soviet Union.

xiii Nicholas Rengger, Just War and International Order The Uncivil Condition in World Politics (Cambridge:

Cambridge University Press, 2013)

xiv Mary Kaldor, New and Old Wars: Organised Violence in a Global Era, (Cambridge: Polity, 2012.

${ }^{x v}$ Michael Ignatieff, The Warrior's Honour Ethnic War and the Modern Conscience (1998)

xvi Nicholas Rengger and Caroline Kennedy, The New Assassination Bureau: On the 'Robotic Turn' in

Contemporary War' Carnegie Council for Ethics in International Affairs, November 6, 2012, carnegiecouncil.org/publication/ethics online.
} 